\title{
Molecular mimicry between cardiac myosin and Trypanosoma cruzi antigen B13: identification of a B13-driven human $\mathrm{T}$ cell clone that recognizes cardiac myosin
}

L.C.J. Abel, J. Kalil and E. Cunha-Neto

\author{
Laboratório de Imunologia de Transplantes, Instituto do Coração, \\ Hospital das Clínicas, Faculdade de Medicina, Universidade de São Paulo, \\ São Paulo, SP, Brasil
}

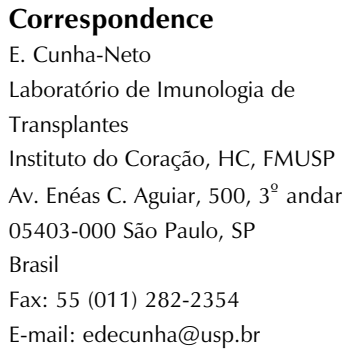

Presented at the XII Annual Meeting of the Federação de Sociedades de Biologia Experimental, Caxambu, MG, Brasil, August 27-30, 1997.

Research supported by FAPESP (No. 95/4762-2).

$\ldots \ldots \ldots \ldots \ldots \ldots \ldots$

Received May 15, 1997 Accepted September 8, 1997

\begin{abstract}
Previous reports from our group have demonstrated the association of molecular mimicry between cardiac myosin and the immunodominant Trypanosoma cruzi protein B13 with chronic Chagas' disease cardiomyopathy at both the antibody and heart-infiltrating $\mathrm{T}$ cell level. At the peripheral blood level, we observed no difference in primary proliferative responses to $T$. cruzi $\mathrm{B} 13$ protein between chronic Chagas' cardiopathy patients, asymptomatic chagasics and normal individuals. In the present study, we investigated whether T cells sensitized by $T$. cruzi $\mathrm{B} 13$ protein respond to cardiac myosin. $\mathrm{T}$ cell clones generated from a B13-stimulated T cell line obtained from peripheral blood of a B13-responsive normal donor were tested for proliferation against B13 protein and human cardiac myosin. The results showed that one clone responded to B13 protein alone and the clone FA46, displaying the highest stimulation index to $\mathrm{B} 13$ protein $(\mathrm{SI}=25.7)$, also recognized cardiac myosin. These data show that B13 and cardiac myosin share epitopes at the $\mathrm{T}$ cell level and that sensitization of a $\mathrm{T}$ cell with B13 protein results in response to cardiac myosin. It can be hypothesized that this also occurs in vivo during T. cruzi infection which results in heart tissue damage in chronic Chagas' disease cardiomyopathy.
\end{abstract}

Chronic Chagas' disease cardiomyopathy (CCC) is the most important clinical form of Chagas' disease, characterized by dilated cardiomyopathy that may lead to a fatal outcome, affecting about $25-30 \%$ of infected individuals 5-30 years after primary infection $(1,2)$. Although the infectious etiology of Chagas' disease is beyond doubt, the direct role of Trypanosoma cruzi in the pathogenesis of chronic Chagas' disease car-
Key words - Molecular mimicry - Crossreactive T cells - Cardiac myosin

- Trypanosoma cruzi

- Chagas' disease diomyopathy is still a subject of debate. The presence of a diffuse, $\mathrm{T}$ cell-rich lymphomonocytic infiltrate with attending cardiomyocyte damage, along with the scarcity of T. cruzi parasites in situ (3-6), implicates infiltrating T cells as the ultimate effectors of heart tissue damage. T cell clones infiltrating CCC heart lesions from areas devoid of $T$. cruzi have been reported to recognize cardiac myosin in molecular mimicry with $T$. 
cruzi proteins (7); others have suggested that, where present, T. cruzi may elicit a focal $\mathrm{T}$ cell infiltrate in the affected heart $(8,9)$.

Several lines of evidence argue against a direct role of the parasite and support autoimmunity as the pathogenic mechanism underlying $\mathrm{CCC}$, i.e., the long time from primary infection to cardiac disease (1), the scarcity of parasites in the heart $\mathrm{T}$ cell-rich inflammatory lesion (6), and the passive transfer of heart lesions by CD4+ T cells from $T$. cruzi-infected mice (10).

The best established autoimmunity-inducing mechanism is molecular mimicry $(11,12)$ whereby a response to an epitope from an infecting pathogen can elicit antibodies or $\mathrm{T}$ cells that can by crossreaction recognize homologous epitopes on self-antigens. Since the 1970's, several groups have published evidence of molecular mimicry at the antibody level in experimental and human Chagas' disease, but they failed to demonstrate that crossreactive antibodies are associated with CCC or other symptomatic clinical forms of Chagas' disease, or the postulated crossreactive self-antigen was not expressed specifically in target organs in Chagas' disease, as reviewed recently (13).

Cardiac myosin is the most abundant heart protein, and a major heart-specific autoantigen for both CD4+ T cells (14) and antibodies (15) in murine models of CCC, which suggests its possible relevance in human disease.

While searching for a candidate sequence which defined heart-specific self-antigen in molecular mimicry with $T$. cruzi, we identified a heart-specific epitope (residues 14421447, AAALDK) of cardiac myosin heavy chain which displayed molecular mimicry with a secondary epitope (hexapeptide AAAGDK from 12-mer tandem repeats) of the immunodominant recombinant B13 protein from T. cruzi (16). Cardiac myosin-B13 crossreactive antibodies were present in $100 \%$ of CCC sera tested but only $14 \%$ of the asymptomatic sera tested showed a statistically significant difference $\left(\mathrm{P}=2.3 \times 10^{-6}\right)$. At the $\mathrm{T}$ cell level, it has been shown that $\mathrm{T}$ cell clones obtained from the heart lesions of CCC patients crossreactively recognize cardiac myosin and B13 protein, while showing no response to $T$. cruzi lysate or other recombinant $T$. cruzi antigens (7). The finding of such crossreactive clones in the heart of a $\mathrm{CCC}$ patient may suggest that a $\mathrm{T}$ cell clone specific for B13 and stimulated upon contact with $T$. cruzi recirculated to the heart where it could be reactivated after finding a B13 crossreactive myosin epitope.

In order to test the hypothesis that primary sensitization to B13 protein elicits clones that are crossreactive to cardiac myosin, we generated a B13-specific T cell line from a non- $T$. cruzi-infected individual who displayed a positive peripheral blood proliferative response to $\mathrm{B} 13(\mathrm{SI}=3.0)$. We have recently found that some normal, non- $T$. cruzi-infected individuals respond to $T$. cruzi B13 protein tandem repeats in the absence of prior contact with $T$. cruzi (17), probably by crossreactive recognition of a B13-like ubiquitous epitope (Abel LCJ, Rizzo LV, Faé KC, Albuquerque F, Goldberg AC, Ianni B, Mady C, Cunha-Neto EC and Kalil J, unpublished data). That the $\mathrm{T}$ cell response to recombinant B13 in normal individuals is directed to the $T$. cruzi-derived tandem repeat sequence is further demonstrated by the absence of response to $\beta$-galactosidase (the fusion protein support) and the response to B13-derived synthetic peptides (data not shown). Furthermore, B13 is recognized in an MHC-restricted manner even by normal individuals, thus dismissing a putative superantigenicity of $\mathrm{B} 13$ protein (Abel LCJ, Rizzo LV, Faé KC, Albuquerque F, Goldberg AC, Ianni B, Mady C, Cunha-Neto EC and Kalil J, unpublished data). Recognition of Plasmodium falciparum $(18,19)$ and $T$. cruzi (20) antigens by peripheral blood mononuclear cells (PBMC) from non-exposed donors has been previously observed. The $\mathrm{T}$ 
cells responsive to $P$. falciparum presented a CD4+, CD45 Ra+ phenotype (21) and are thought to be sensitized to ubiquitous crossreactive antigens.

In the present study, clones were derived from a B13-specific T cell line established from peripheral blood of T.cruzi-seronegative individual FA (presenting an HLA class II profile: DR1, DR4/DQA1* 03,0101/ DQB1* 0501,0302), displaying a positive primary PBMC proliferative response to $\mathrm{B} 13$.

The establishment of the $\mathrm{T}$ cell line and clones was essentially as described by Sinigaglia et al. (22). Briefly, PBMC (2 x 106/well, 24-well Corning culture dish) were incubated with B13 protein $(5 \mu \mathrm{g} / \mathrm{ml})$ in $1 \mathrm{ml}$ of complete medium (Dulbecco's modified Eagle's medium $+10 \%$ inactivated human serum + penicillin/gentamicin, sodium pyruvate and $\mathrm{L}$-glutamine). Six days later, $20 \mathrm{U} /$ $\mathrm{ml}$ recombinant human IL-2 (Hofmann La Roche, Nutley, NJ) was added to the culture medium, and IL-2-containing fresh medium was then added every three days. One week later, the line was expanded by re-stimulation with phytohemagglutinin (PHA, $5 \mu \mathrm{g}$ / $\mathrm{ml}$ ), $20 \mathrm{U} / \mathrm{ml} \mathrm{IL-2}$ and irradiated (5000 rads) PBMC (10\%well), and after an additional two weeks lymphoblasts were cloned by limiting dilution ( 0.3 cells/well) in the presence of irradiated PBMC (104/well), and PHA $(5 \mu \mathrm{g} / \mathrm{ml})$ in complete medium with 20 $\mu \mathrm{l} /$ well on Terasaki plates. Growing clones from Terasaki wells were transferred to 24well plates and expanded by further cycles of stimulation with PHA + irradiated PBMC in the presence of IL-2 as above. Eight such clones reached adequate numbers and were subject to antigen-induced proliferation assays.

As shown in Figure 1, two clones displayed positive proliferative responses to

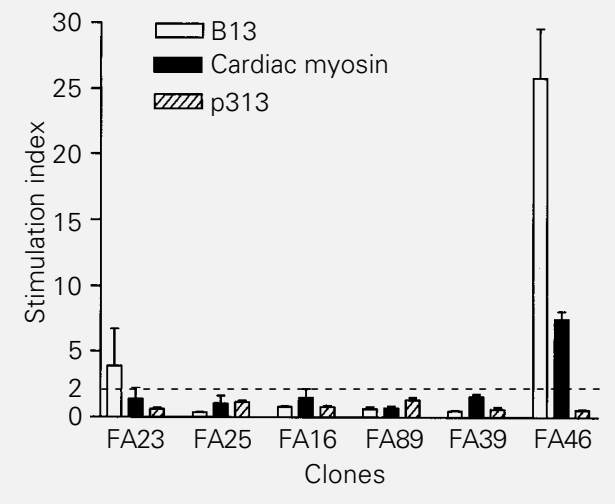

B13 protein. While clone FA23 recognized B13 protein exclusively, clone FA46, which displayed the highest proliferative response to B13, also responded significantly to human cardiac myosin heavy chain. None of the clones studied recognized the unrelated peptide antigen 313 of Streptococcus pyogenes M5 protein (163-177).

Our results show that sensitization by $T$. cruzi B13 protein may elicit $\mathrm{T}$ cell clones capable of displaying crossreactive recognition of human cardiac myosin heavy chain.

Given the fact that $T$. cruzi can induce both macrophage costimulatory activity (23) and IL-12 production in mice (24) and humans (Cunha-Neto E, Rizzo LV, Abel LCJ, Albuquerque F, Bocchi E, Bacal F, Carrara D, Mady C, Ianni B, Gazzinelli RT, Almeida IC, Travassos L and Kalil J, unpublished data), it is possible that T. cruzi infection may fully trigger the pathogenic potential of crossreactive T cells in individuals who carry them. Together with the finding of B13cardiac myosin crossreactive $T$ cell clones in the heart infiltrate of CCC patients (7), the present data lend support to the idea that $\mathrm{T}$ cell clones sensitized at the periphery by B13 during $T$. cruzi infection may migrate to the heart and participate in heart tissue damage in CCC.
Figure 1 - Proliferation assays of B13-driven PBMC $T$ cell clones. $T$ cell clones $\left(4 \times 10^{4}\right.$ cells/well) were incubated with irradiated autologous PBMC $\left(10^{5} /\right.$ well) under various antigen test conditions in complete medium in 96well plates at $37^{\circ} \mathrm{C}$ in a humidified $5 \% \mathrm{CO}_{2}$ atmosphere. After $72 \mathrm{~h}$ wells were pulsed with 1 $\mu \mathrm{Ci}\left[{ }^{3} \mathrm{H}\right]$-thymidine (Amersham Corp., Arlington Heights, IL) for $18 \mathrm{~h} .\left[{ }^{3} \mathrm{H}\right]$-Thymidine incorporation was measured with a MATRIX 96 direct beta counter (Packard, Canberra, Australia). B13 protein was prepared as described elsewhere (25), applied to a polymyxin B column to remove endotoxin as described previously (26), and used at a final concentration of $5 \mu \mathrm{g} / \mathrm{ml}$. A human cardiac myosin heavy chain nitrocellulose suspension was prepared as described previously (16). Unrelated M5 protein peptide 313 (p313) was prepared using Merrifield solidphase t-Boc technology and tested at $5 \mu \mathrm{g} / \mathrm{ml}$. The results are reported as mean \pm SD stimulation index (SI) (test cpm/control $\mathrm{cpm}$ ). SI values $>2.0$ (dotted line) were considered to be positive. 


\section{References}

1. Macêdo V (1982). Chagas' disease (American trypanosomiasis). In: Wyngaarden JB \& Smith LH (Editors), Cecil Textbook of Medicine. 16th edn. W.B. Saunders Company, Philadelphia, 1728-1731.

2. Schmuñis GA (1987). Autoimmunity in Chagas' disease. Memórias do Instituto Oswaldo Cruz, 82 (Suppl 1): 287-310.

3. Bellotti G, Bocchi EA, Moraes AV, Higuchi $M L$, Barbero-Macial M, Sosa E, EstevesFilho A, Kalil R, Weiss R, Jatene A \& Pileggi $F$ (1996). In vivo detection of Trypanosoma cruzi antigens in hearts of patients with chronic Chagas' heart disease. American Heart Journal, 131: 301-307.

4. Jones EM, Coley DG, Tostes S, Lopes ER, Vnecank-Jones CL \& McCurley TL (1993). Amplification of a Trypanosoma cruzi DNA sequence from inflammatory lesions in human chagasic cardiomyopathy. American Journal of Tropical Medicine and Hygiene, 48: 348-357.

5. Brandariz S, Schijamn A, Vigliano C, Viotti R \& Levin M (1996). Detection of parasite DNA in Chagas' heart disease. Lancet, 346: 1370-1371.

6. Higuchi ML, De Brito $T$, Reis $M M$, Barbosa A, Bellotti G, Pereira-Barreto AC \& Pileggi $F$ (1993). Correlation between $T$. cruzi parasitism and myocardial inflammatory infiltrate in human chronic chagasic myocarditis: light microscopy and immunohistochemical findings. Cardiovascular Pathology, 2: 101-106.

7. Cunha-Neto E, Coelho V, Guilherme L, Fiorelli A, Stolf N \& Kalil J (1996). Autoimmunity in Chagas' disease: identification of cardiac myosin-B13 Trypanosoma cruzi protein crossreactive $T$ cell clones in heart lesions of a chronic Chagas' cardiomyopathy patient. Journal of Clinical Investigation, 98: 1709-1712.

8. Higuchi ML, Reis MM, Aiello VD, Benvenuti LA, Gutierrez PS, Bellotti G \& Pileggi $F$ (1997). Association of an increase in $\mathrm{CD} 8+\mathrm{T}$ cells with the presence of Trypanosoma cruzi antigens in chronic human chagasic myocarditis. American Journal of Tropical Medicine and Hygiene, 56: 485-489.

9. Tarleton $R L$, Zhang $L$ \& Downs $M O$ (1997). "Autoimmune rejection" of neonatal heart transplants in experimental Chagas' disease is a parasite-specific response to infected host tissue. Proceedings of the National Academy of Sciences, USA, 94: 3932-3937.
10. Ribeiro-dos-Santos R, Rossi MA, Laus JL, Santana Silva J, Savino W \& Menguel J (1992). Anti CD4+ treatment abrogates rejection and reestablishes long-term tolerance to syngeneic newborn hearts grafted in mice chronically infected with Trypanosoma cruzi. Journal of Experimental Medicine, 175: 29-39.

11. Klein J (1990). Immunology. Blackwell Scientific Publications, Inc., London.

12. Wucherpfennig K \& Strominger J (1995). Molecular mimicry in T-cell mediated autoimmunity: viral peptides activate human T cell clones specific for myelin basic protein. Cell, 80: 695-705.

13. Kalil J \& Cunha-Neto E (1996). Autoimmunity in Chagas' disease cardiomyopathy: fulfilling the criteria at last? Parasitology Today, 12: 396-399.

14. Rizzo LV, Cunha-Neto E \& Teixeira A (1989). Specific inhibition of reactivity of $\mathrm{CD} 4+\mathrm{T}$ cells against myosin in mice chronically infected with Trypanosoma cruzi. Infection and Immunity, 57: 26402644.

15. Tibbetts RS, McCormick TS, Rowland EC, Miller SD \& Engman DM (1994). Cardiac antigen-specific autoantibody production is associated with cardiomyopathy in Trypanosoma cruzi-infected mice. Journal of Immunology, 152: 1493-1499.

16. Cunha-Neto E, Duranti M, Gruber A, Zingales B, Messias I, Stolf N, Bellotti G, Pileggi F, Patarroyo ME \& Kalil J (1995). Autoimmunity in Chagas' disease cardiopathy: biological relevance of a cardiac myosin-specific epitope crossreactive to an immunodominant Trypanosoma cruzi antigen. Proceedings of the National Academy of Sciences, USA, 92: 3541-3545.

17. Albuquerque $F$, Cunha-Neto E, Duranti MA, Ianni B, Mady C \& Kalil J (1995). Proliferative response of peripheral blood T lymphocytes to recombinant T. cruzi B13 protein in chronic cardiopathy and asymptomatic Chagas' disease patients. Memórias do Instituto Oswaldo Cruz, 90 (Suppl I): 150.

18. Zevering $Y$, Amante F, Smillie A, Currier J, Smith G, Houghten RA \& Good MF (1992). High frequency of malaria-specific $T$ cells in non-exposed humans. European Journal of Immunology, 22: 689-696.
19. Currier J, Sattabongkot J \& Good MF (1992). Natural T cells responsive to malaria: evidence implicating cross-reactivity in the maintenance of TCR alfa beta+ malaria-specific responses from non-exposed donors. International Immunology, 4: 985-994.

20. Piuvezam MR, Russo DM, James MB, Yasir AW, Skeiky YAW, Grabstein KH \& Reed SG (1993). Characterization of response of normal human T cells to Trypanosoma cruzi antigens. Journal of Immunology, 150: 916-924.

21. Fern J \& Good M (1992). Promiscuous malaria peptide epitope stimulates CD45Ra T cells from peripheral blood of nonexposed donors. Journal of Immunology, 148: 907-913.

22. Sinigaglia $F$, Romagnoli $P$, Guttinger $M$, Takacs B \& Pink RL (1991). Selection of $T$ cell epitopes and vaccine engineering. Methods in Enzymology, 203: 370-386.

23. Frosch S, Kuntzlin D \& Fleischer B (1997). Infection with Trypanosoma cruzi selectively upregulates B7-2 molecules on macrophages and enhances their costimulatory activity. Infection and Immunity, 65: 971-977.

24. Aliberti JCS, Cardoso MAG, Martins GA, Gazzinelli RT, Vieira LQ \& Silva JS (1996). Interleukin-12 mediates resistance to Trypanosoma cruzi in mice and is produced by murine macrophages in response to live trypomastigotes. Infection and Immunity, 64: 1961-1967.

25. Gruber A \& Zingales B (1993). Trypanosoma cruzi: Characterization of two recombinant antigens with potential application in the diagnosis of Chagas' disease. Experimental Parasitology, 76: 1-12.

26. Vogel SN, Hilfiker ML \& Caulfield MJ (1983). Endotoxin-induced T lymphocyte proliferation. Journal of Immunology, 130: 1774-1779 